\title{
PENGARUH BEBAN KERJA DAN MOTIVASI KERJA TERHADAP KEPUASAN KERJA PEGAWAI PADA LAPAS KELAS IIB SINGARAJA
}

\author{
D. G. M. Astuti ${ }^{1}$, N. M. D. A. Mayasari ${ }^{2}$ \\ 1,2Jurusan Manajemen, Fakultas Ekonomi, Universitas Pendidikan Ganesha, Singaraja \\ e-mail: desakgedemeriastuti24@gmail.com,dwi.mayasari@undiksha.ac.id
}

\begin{abstract}
Abstrak
Penelitian ini bertujuan untuk menguji pengaruh: (1) beban kerja dan motivasi kerja terhadap kepuasan kerja, (2) beban kerja terhadap motivasi kerja, (3) beban kerja terhadap kepuasan kerja, (4) motivasi kerja terhadap kepuasan kerja pada pegawai pada LAPAS kelas IIB Singaraja. Desain penelitian yang digunakan adalah kuantitatif kausal. Subjek pada penelitian ini adalah pegawai pengamanan Lapas kelas Ilb Singaraja, objek pada penelitian ini adalah beban kerja, motivasi kerja, dan kepuasan kerja. Populasi pada penelitian ini berjumlah 35 orang responden Data yang dikumpulkan dengan kuesioner dan dianalisis dengan menggunakan analisis jalur. Hasil dari penelitian menunjukkan bahwa: (1) Beban kerja dan motivasi kerja berpengaruh secara signifikan terhadap kepuasan kerja, (2) Beban kerja berpengaruh secara negatif terhadap motivasi kerja, (3) Beban kerja berpengaruh secara negatif terhadap kepuasan kerja, (4) Motivasi kerja berpengaruh secara positif terhadap kepuasan kerja.
\end{abstract}

Kata-kata kunci: beban kerja, motivasi, kepuasan kerja

\section{Abstract}

This study aims to examine the effect of: (1) workload and work motivation on job satisfaction, (2) workload on work motivation, (3) workload on job satisfaction, (4) work motivation on job satisfaction for employees at class LAPAS IIB Singaraja. The research design used is quantitative causal. The subject of this research is the security officer of Class Ilb Singaraja Prison, the object of this research is workload, work motivation, and job satisfaction. The population in this study was 35 respondents. Data collected by questionnaire and analyzed using path analysis. The results of the study indicate that: (1) Workload and motivation have a significant effect on job satisfaction, (2) Workload has a negative effect on work motivation, (3) Workload has a negative effect on job satisfaction, (4) Work motivation has a significant effect on job satisfaction. positive on job satisfaction.

Keywords: workload, motivation, job satisfaction

\section{Pendahuluan}

Setiap organisasi didirikan guna mencapai tujuan yang telah ditetapkan, salah satu penentu keberhasilan suatu organisasi dalam mencapai tujuannya adalah aspek sumber daya manusia. Bagian terpenting dari manajemen sumber daya manusia yakni mengenai kepuasan kerja, setiap perusahaan perlu memperhatikan kepuasan kerja pegawai, kepuasan kerja pegawai harus lebih tinggi diantara para pekerja, hal tersebut menjadi salah satu syarat guna meningkatkan kemampuan kerja, kinerja, kualitas serta pelayanan. Sumber daya yang baik akan tercipta apabila suatu perusahaan dapat memenuhi kepuasan kerja karyawan. Handoko (2010) mengemukakan bahwa kepuasan kerja adalah perasaan menyenangkan atau tidak menyenangkan dimana para karyawan memandang pekerjaannya, kepuasan kerja menunjukkan sikap seseorang mengenai pekerjaannya, kepuasan kerja terlihat dari bagaimana karyawan dalam memandang pekerjaannya dan segala hal yang berkaitan dengan pekerjaannya. Kepuasan kerja yang dirasakan oleh pegawai akan memberikan dampak positif bagi organisasi maupun bagi pegawai itu sendiri. Pegawai yang merasa puas terhadap pekerjaannya akan setia kepada organisasi tempatnya bekerja dan akan menunjukkan raut wajah yang ceria ketika bekerja, menyelesaikan pekerjaan dengan baik dan memiliki semangat kerja yang tinggi. Selain itu tingkat kepuasan kerja pegawai yang tinggi juga dapat memberikan keuntungan pada organisasi seperti pada absensi pegawai dan berbagai keluhan lain saat bekerja. Sebaliknya, jika kepuasan kerja pegawai rendah maka akan terlihat pada 
perilaku pegawai yang cenderung negatif, seperti pegawai malas dalam menyelesaikan pekerjaannya, tidak hadir tepat waktu, sering melakukan bolos kerja, dan bermain Handphone saat jam kerja berlangsung.

Lembaga pemasyarakatan yang selanjutnya disingkat menjadi LAPAS adalah bagian dari unit pelaksana teknis pada jajaran Kementrian Hukum dan Hak Asasi Manusia yang memiliki peran utama dalam melaksanakan pemasyarakatan narapidana/ anak didik. Adapun fungsi LAPAS yakni melakukan fungsi pembinaan yang merupakan proses pemasyarakatan sebagai wujud pembaharuan pidana yang sebelumnya dikenal sebagai penjara juga merupakan suatu proses pembinaan narapidana yang memandang narapidana sebagai makhluk Tuhan, individu dan anggota masyarakat. Tujuan pelaksanaan pembinaan narapidana dengan sistem pemasyarakatan guna menjadikan narapidana sebagai manusia seutuhnya, sebagaimana telah ditetapkan dalam pembangunan nasional, melalui pendekatan dalam memantapkan iman dan membina mereka agar mampu berintergrasi kembali di dalam kehidupan sehari-hari setelah menjalani masa pidananya.

Lembaga pemasyarakatan kelas IIB Singaraja beralamat di jl. Veteran no. 18, Paket Agung, Kec. Buleleng, Kab. Buleleng. Beban kerja yang cukup berat dialami oleh pegawai pengamanan LAPAS Kelas IIB Singaraja yang diakibatkan oleh kelebihan kapasitas penghuni tahanan sebnayak 132 orang. Menurut Sugiyanto dalam Suwatno dan Priansa (2011:251) beban kerja merupakan pemanfaatan energi utama dan energi cadangan yang dimiliki. Pekerjaan dianggap berlebih (overload) apabila energi utama dimanfaatkan secara total dan masih memerlukan energi cadangan dalam menyelesaikan pekerjaan. Sebaliknya tugas dipanggap ringan (underload) jika tidak memerlukan banyak energidalam menyelesaikan pekerjaan. Tingginya over kapasitas pada LAPAS kelas IIB Singaraja tentunya berdampak pada beban kerja yang diterima pegawai LAPAS. Selain beban kerja, motivasi juga dapat mempengaruhi kepuasan kerja pegawai. Motivasi adalah rangsangan yang muncul dari dalam diri seseorang untuk menggerakkan seseorang agar dapat melakukan sesuatu, motivasi muncul dikarenakan adanya dorongan baik berupa materiil maupun non materiil yang harus dipenuhi untuk mencapai kepuasan. Sebagaimana yang dikemukakan oleh Wursanto (2010:131), motivasi merupakan alasan, rangsangan yang muncul dari diri seseorang yang dapat menyebabkan seseorang melakukan tindakan atau berbuat sesuatu. Motivasi pegawai dipengaruhi oleh faktor minat, upah yang diterima, kebutuhan rasa aman dan keselamatan, hubungan interrpersonal dan peluang untuk bekerja. Berdasarkan informasi yang diperoleh, masih adanya petugas yang tidak melaksanakan tugas dengan baik ataupun menyimpang dari hukum yang berlaku. Salah satunya kasus yang terjadi pada Maret 2020 dimana ditemukan oknum Sipir Lapas Singaraja yang diketahui menyimpan narkoba jenis Sabu dalam mie gelas.

Berdasarkan hasil wawancara dengan kepala urusan kepegawaian dapat diketahui bahwa pemberian reward kepada pegawai yang berprestasi atas pekerjaannya dilakukan setiap tahun. Pada tahun 2019 reward yang diberikan dapat berupa piagam penghargaan, surat keputusan (SK) dan uang saku sebesar Rp.500.000 sedangkan pada tahun 2020 terjadi perubahn reward yang diberikan dimana pada tahun ini reward diberikan berupa piagam penghargaan, surat keputusan (SK) dan hadiah berupa jam dinding dengan logo dinas. hal ini menunjukkan bahwa terjadi penurunan reward yang diberikan. Hal tersebut tentunya berpengaruh terhadap kepausan kerja pegawai, dimana reward yang diberikan berkurang dari tahun sebelumnya. Kepuasan kerja pegawai pada LAPAS kelas IIB Singaraja masih dikatakan rendah, hal ini ditunjukkan dengan kehadiran pegawai, dimana dari hasil wawancara dapat diketahui bahwa banyak pegawai yang sering melakukan bolos kerja, dimana pegawai datang hanya untuk melakukan absensi, setelah itu pergi meninggalkan kantor dan kembali lagi untuk melakukan absen sore kasus seperti ini juga sering terjadi ketika pimpinan sedang tidak ada ditempat. Hal ini menandakan bahwa minat dan kepuasan kerja pegawai masih rendah, sehingga pegawai cenderung meninggalkan tugas dan tanggung jawabnya.

Berdasarkan penelitian yang telah dilakukan oleh Kamil (2016) menunjukkan bahwa beban kerja dan motivasi kerja secara simultan memiliki pengaruh signifikan terhadap kepuasan kerja pada karyawan tetap. Begitu juga dengan hasil penelitian Anggraini (2019) yang menunjukkan bahwa beban kerja dan motivasi berpengaruh secara simultan terhadap kepuasan kerja karyawan. Secara teoritik penelitian ini dilandasi beberapa teori tentang beban 
kerja, motivasi kerja, dan kepuasan kerja. Robbins dan Judge (2008) menyatakan kepuasan kerja merupakan sikap yang umumnya dirasakan seseorang mengenai pekerjaannya, dimana sikap tersebut timbul dikarenakan jumlah penghargaan yang diterima pekerja berbeda dengan jumlah yang diyakini seharusnya diterima. Hal serupa juga dikemukakan oleh Gibson, Ivancenvich, dan Donely (2000) yang mengemukakan kepuasan kerja sebagai sikap yang dirasakan pekerja tentang pekerjaannya. Menurut Hasibuan (2014) kepuasan kerja dipengaruhi oleh faktor timbal balik yang sesuai, penempatan posisi yang tepat sesuai dengan kompetensi, ukuran pekerjaan yang diterima, situasi dan kondisi kerja, perlengkapan yang menunjang pelaksanaan pekerjaan, perilaku pimpinan dalam kepemimpinannya dan sikap pekerjaan monoton atau tidak. Sownya dan Panchanatham (2011) menyebutkan bahwa indikator -indikator yang mempengaruhi kepuasan kerja dibagi menjadi lima yaitu; (1) gaji, (2) aspek organisasi, (3) perilaku atasan, (4) pekerjaan dan kondisi kerja, (5) perilaku rekan kerja. Menurut Steve M.Jex mengemukakan "Workload can be defined as the amount of work an employee has to do in a given period of time". Dapat diterjemahkan secara bebas bahwa beban kerja merupakan sejumlah pekerjaan yang harus dilakukan karyawan dalam kurun waktu tertentu. Indikator beban kerja disini menggunakan indikator yang dikemukakan oleh Koesomowidjojo (2007), yang meliputi antara lain; (1) koondisi pekerjaan, (2) penggunaan waktu kerja, dan (3) target yang ingin dicapai. Hasibuan (2014) mengemukakan, motivasi adalah dorongan yang menciptakan semangat kerja seseorang agar dapat bekerja sama, bekerja efektif dan selaras dengan segala daya upayanya guna mencapai kepuasan. Handoko (2005), menyatakan bahwa motivasi adalah keadaan dalam diri seseorang yang mendorong keinginan individu guna melakukan kegiatan-kegiatan tertentu untuk mencapai suatu tujuan. Indikator Motivasi menurut Hasibuan (2014) adalah sebagai berikut: (1) kebutuhan fisik, (2) rasa aman dan keselamatan, (3) kebutuhan sosial, (4) kebutuhan akan penghargaan, dan (5) kebutuhan perwujudan diri.

Melihat kesenjangan fakta masalah yang terdapat di LAPAS kelas IIB Singaraja dengan teori yang ada maka perlu untuk melakukan penelitian dengan judul "Pengaruh Beban Kerja dan Motivasi Kerja Terhadap Kepuasan Kerja Pegawai pada Lapas Kelas IIB Singaraja". Tujuan dari penelitian ini untuk menguji: (1) Pengaruh beban kerja dan motivasi kerja terhadap kepuasan kerja kerja pada pegawai LAPAS kelas IIB Singaraja. (2) Pengaruh beban kerja terhadap motivasi kerja pada pada pegawai LAPAS kelas IIB Singaraja. (3) Pengaruh beban kerja terhadap kepuasan kerja pada pegawai pada LAPAS kelas IIB Singaraja. (4) Pengaruh motivasi kerja terhadap kepuasan kerja pada pegawai pada LAPAS kelas IIB Singaraja. Hasil Penelitian ini diharapkan dapat memberikan manfaat teoritis dan manfaat praktis. Secara teoritis diharapkan nantinya dapat membantu dalam pembelajaran serta mengaplikasikan ilmu pengetahuan. Secara praktis hasil penelitian ini diharapkan dapat memberikan saran, masukan, serta informasi yang bermanfaat yang berkaitan dengan perencanaan strategi untuk meningkatkan kepuasan kerja pegawai lapas kelas IIB Singaraja. Dengan demikian pegawai akan merasa nyaman dan puas akan apa yang diterima karena setimpal dengan apa yang sudah disumbangkan kepada organisasi tersebut.

\section{Metode}

Penelitian ini dilakukan untuk mengetahui pengaruh beban kerja $\left(X_{1}\right)$ dan motivasi kerja $\left(\mathrm{X}_{2}\right)$ terhadap kepuasan kerja $(\mathrm{Y})$ pada pegawai LAPAS kelas Ilb Singaraja. Variabel yang terdapat dalam penelitian ini yaitu variabel bebas yang mempengaruhi dan variabel terikat yang merupakan variabel yg di pengaruhi atau yang menjadi akibat karena adanya variabel bebas. Dalam penelitian ini yang di maksud variabel bebas yaitu beban kerja dan motivasi kerja, sedangkan variabel terikat yaitu kepuasan kerja.

Berdasarkan karakteristik masalah yang diteliti maka penelitian ini menggunakan rancangan kuantitatif kausal. Penelitian kuantitatif kausal yaitu penelitian yang bertujuan utama untuk membuktikan hubungan sebab akibat atau kata lain menganalisis bagaimana satu variabel mempengaruhi variabel lainnya. Rancangan penelitian kuantitatif kausal terdiri dari beberapa tahapan (1) merumuskan masalah, (2) mengkaji teori, (3) merumuskan hipotesis, (4) mengumpulkan data, (5) mengolah data, dan (6) menarik kesimpulan. 
Subjek dalam penelitian ini adalah Lembaga Pemasyarakatan Kelas IIB Singaraja, sedangkan objek dalam penelitian ini adalah beban kerja, motivasi kerja, dan kepuasan kerja pegawai pada LAPAS Kelas IIB Singaraja. Penelitian ini merupakan penelitian populasi, karena seluruh populasi digunakan sebagai responden penelitian. Populasi dalam penelitian ini adalah seluruh pegawai kesatuan pengamanan LAPAS Kelas IIB Singaraja yang berjumlah 35 orang. Metode pengumpulan data pada penelitian ini adalah metode kuesioner dan observasi. Analisis data dalam penelitian ini menggunakan analisis jalur (Path Analysis).

\section{Hasil dan Pembahasan}

Tabel 3.1

Hasil Analisis Jalur Pengaruh Beban Kerja dan Motivasi Kerja Terhadap Kepuasan Kerja

\begin{tabular}{|c|c|c|c|c|c|}
\hline Parameter & $\begin{array}{l}\text { Koefisien } \\
\text { Korelasi } \\
(\mathrm{R})\end{array}$ & $\mathrm{R}^{2}$ & Sig & Keputusan & Simpulan \\
\hline $\mathrm{Pyx}_{1}$ & $-0,458$ & 0,210 & 0,001 & Menolak $\mathrm{H}_{0}$ & $\mathrm{X}_{1}$ berpengaruh terhadap $\mathrm{Y}$ \\
\hline $\mathrm{Pyx}_{2}$ & 0,480 & 0,230 & 0,000 & Menolak $\mathrm{H}_{0}$ & $\mathrm{X}_{2}$ berpengaruh terhadap $\mathrm{Y}$ \\
\hline$P x_{2} x_{1}$ & $-0,686$ & 0,470 & 0,000 & Menolak $\mathrm{H}_{0}$ & $\mathrm{X}_{1}$ berpengaruh terhadap $\mathrm{X}_{2}$ \\
\hline Sig.F & 0,000 & - & - & & - \\
\hline $\operatorname{Ryx}_{1} x_{2}$ & 0,861 & - & - & Menolak $\mathrm{H}_{0}$ & $\begin{array}{l}\mathrm{X}_{1} \text { dan } \mathrm{X}_{2} \text { berpengaruh } \\
\text { terhadap } \mathrm{Y}\end{array}$ \\
\hline$R^{2} \mathrm{yx}_{1} \mathrm{x}_{2}$ & 0,742 & - & - & & $\begin{array}{l}\text { Besar sumbangan pengaruh } \\
X_{1} \text { dan } X_{2} \text { terhadap } Y\end{array}$ \\
\hline
\end{tabular}

Berdasarkan hasil rekapitulasi analisis jalur yang terdapat pada Tabel 3.1 menunjukkan bahwa nilai $p$-value sebesar 0,000 , dimana nilai tersebut $p$-value $<\alpha=0,05$ sehingga hal ini menyatakan bahwa terdapat pengaruh beban kerja dan motivasi kerja terhadap kepuasan kerja pada pegawai LAPAS kelas IIB Singaraja. Pengujian hipotesis kedua yang diuji secara statistik yakni $\mathrm{H}_{0}$. Berdasarkan hasl rekapiulasi analisis jalur yang terdapat pada Tabel 3.1 menunjukkan bahwa nilai $p$-value sebesar 0,000 , dimana nilai tersebut $p$-value $<\alpha=0,05$ sehingga hal ini menyatakan bahwa ada pengaruh beban kerja terhadap motivasi pada pegawai LAPAS kelas IIB Singaraja. Pengujian hipotesis ketiga yang diuji secara statistik adalah $\mathrm{H}_{0}$. Dari hasil rekapitulasi analisis jalur pada Tabel 4.4 menyatakan bahwa nilai $p$-value sebesar 0,001 , dimana nilai tersebut $p$-value $<\alpha=0,05$ sehingga hal ini menyatakan bahwa terdapat pengaruh beban kerja terhadap kepuasan kerja pada pegawai LAPAS kelas IIB Singaraja. Pengujian hipotesis keempat yang diuji secara statistik adalah $\mathrm{H}_{0}$. Berdasarkan hasil rekapitulasi analisis jalur pada Tabel 4.4 menyatakan bahwa nilai $p$-value sebesar 0,000 , dimana nilai tersebut $p$-value $<\alpha=0,05$ sehingga hal ini menyatakan bahwa ada pengaruh motivasi kerja terhadap kepuasan kerja pada pegawai LAPAS kelas IIB Singaraja. Besaran jumlah sumbangan pengaruh yang diberikan secara langsung dan tidak langsung dari variabel beban kerja dan motivasi kerja terhadap kepuasan dapat dilihat pada Tabel 3.2.

Tabel 3.2

Besaran Jumlah Sumbangan Pengaruh Variabel Beban Kerja dan Motivasi Kerja Terhadap Kepuasan Kerja

\begin{tabular}{|c|c|c|c|c|}
\hline \multirow[b]{2}{*}{ Keterangan } & \multicolumn{2}{|r|}{$r^{\prime}$} & \multirow[b]{2}{*}{$\begin{array}{c}\text { Besar } \\
\text { Sumbangan }\end{array}$} & \multirow[b]{2}{*}{$\begin{array}{c}\text { Persentase } \\
(\%)\end{array}$} \\
\hline & Rumus & Perhitungan & & \\
\hline $\begin{array}{l}\text { Besar pengaruh } \\
\text { langsung } X_{1} \\
\text { terhadap } Y\end{array}$ & $\left(P_{y x} 1\right)^{2}$ & $(-0,458)^{\star}(-0,458)$ & 0,210 & 21,0 \\
\hline $\begin{array}{l}\text { Besar pengaruh } \\
\text { tidak langsung } \\
X_{1} \text { terhadap } Y \\
\text { melalui } X_{2}\end{array}$ & $\begin{array}{c}\text { Pyx1.Px2x1. } \\
\text { Pyx2 }\end{array}$ & $\begin{array}{c}(-0,458)^{\star} \\
(-0,686)^{*}(0,480)\end{array}$ & 0,151 & 15,1 \\
\hline
\end{tabular}




\begin{tabular}{|c|c|c|c|c|}
\hline Keterangan & Rumus & Perhitungan & $\begin{array}{c}\text { Besar } \\
\text { Sumbangan }\end{array}$ & $\begin{array}{c}\text { Persentase } \\
(\%)\end{array}$ \\
\hline $\begin{array}{l}\text { Besar pengaruh } \\
\text { total } X_{1} \\
\text { terhadap } Y\end{array}$ & $\begin{array}{c}(P y \times 1)^{2}+ \\
\text { Pyx1.Rx2x1. } \\
\text { Pyx2 }\end{array}$ & $0,210+0,151$ & 0,361 & 36,1 \\
\hline $\begin{array}{l}\text { Besar pengaruh } \\
X_{2} \text { terhadap } Y\end{array}$ & $(\operatorname{Pyx} 2)^{2}$ & $(0,480)^{\star}(0,480)$ & 0,230 & 23,0 \\
\hline $\begin{array}{l}\text { Besar pengaruh } \\
\text { total } X_{1} \text { dan } X_{2} \\
\text { terhadap } Y\end{array}$ & $R^{2} \mathrm{yx}_{1} \mathrm{x}_{2}$ & $0,861^{*} 0,861$ & 0,742 & 74,2 \\
\hline $\begin{array}{l}\text { Besar pengaruh } \\
\text { faktor lain } \\
\text { terhadap Y }\end{array}$ & $1-R^{2} y x_{1} x_{2}$ & $1-0,742$ & 0,258 & 25,8 \\
\hline
\end{tabular}

Data hasil penelitian pada Tabel 3.2 menunjukkan bahwa besaran sumbangan pengaruh secara langsung pada variabel beban kerja dan motivasi kerja terhadap kepuasan kerja adalah 0,742 . Hasil tersebut menyatakan bahwa sebesar $74,2 \%$ kepuasan kerja dipengaruhi oleh variabel beban kerja dan motivasi, sedangkan pengaruh dari variabel lain sebesar $25,8 \%$. Kedua, korelasi variabel beban kerja terhadap motivasi kerja sebesar 0,686 dan besar sumbangan pengaruh adalah $47,0 \%$. Korelasi terebut memiliki arah negatif, hal tersebut menunjukan bahwa beban kerja secara negatif berpengaruh terhadap motivasi kerja. Artinya, beban kerja meningkat, maka motivasi kerja cenderung menurun. Sebaliknya, ssemain rendah beban kerja, maka motivasi kerja akan semakin tinggi. Besar sumbangan pengaruh dari beban kerja terhadap motivasi kerja adalah 53,0\%.

Ketiga, korelasi variabel beban kerja terhadap kepuasan kerja sebesar 0,458 dan besar sumbangan pengaruh adalah $21,0 \%$. Korelasi memiliki arah negatif, hal ini menunjukan bahwa beban kerja berpengaruh secara negatif terhadap kepuasan kerja. Artinya, jika beban kerja semakin tinggi, maka kepuasan kerja akan semakin rendah. Sebaliknya, jika beban kerja semakin rendah, maka kepuasan kerja akan semakin tinggi. Keempat, kekuatan hubungan pengaruh dari motivasi kerja terhadap kepuasan kerja sebesar 0,480 dengan sumbangan pengaruh yang diberikan adalah $23,0 \%$. Korelasi memiliki arah positif, hal ini menyatakan bahwa motivasi kerja secara positif berpengaruh terhadap kepuasan kerja. Artinya, semakin tinggi motivasi kerja, maka kepuasan kerja juga akan semakin meningkat. Namun, semakin rendah motivasi kerja, maka kepuasan kerja akan semakin rendah.

Pengaruh dari masing-masing variabel terhadap kepuasan kerja pada pegawai LAPAS kelas IIB Singaraja dapat digambarkan pada Gambar 3.1.

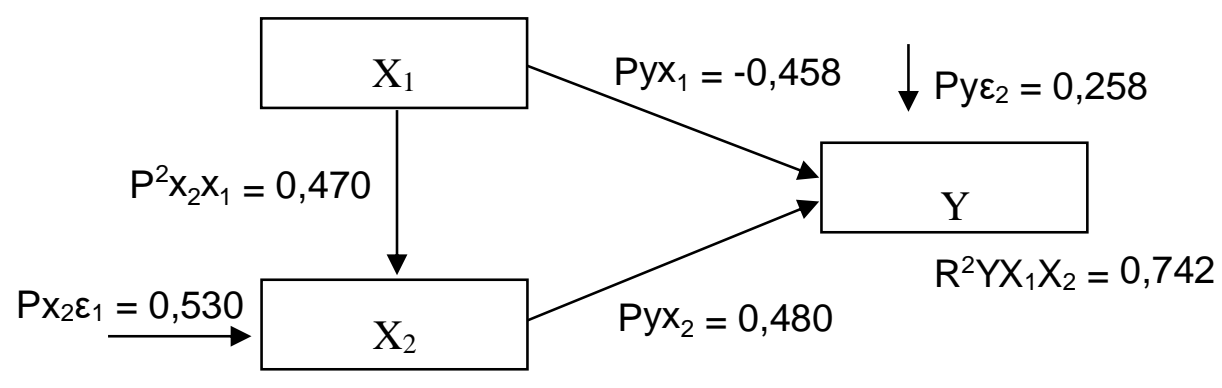

Gambar 3.1

Struktur Pengaruh Variabel Beban Kerja dan Motivasi Kerja Terhadap Kepuasan Kerja

$\begin{array}{lllll}\text { Keterangan: } & \mathrm{X}_{1} & \text { :Beban kerja } & \mathrm{X}_{2} & \text { : Motivasi kerja } \\ & \mathrm{Y} & \text { : Kepuasan kerja } & \mathrm{E} & \text { : Faktor lain }\end{array}$


Dari penelitian yang telah dilakukan maka dapat diketahui bahwa variabel beban kerja dan motivasi kerja berpengaruh signifikan terhadap kepuasan kerja pegawai LAPAS Kelas IIB Singaraja. Hasil ini sesuai dengan pendapat Wibowo (2012), dimana dari hasil tersebut dinyatakan bahwa motivasi kerja memiliki pengaruh positif terhadap kepuasan kerja karyawan, selanjutnya apabila beban kerja tinggi maka kepuasan kerja pegawai cenderung rendah. Pegawai pengamanan lapas di dominasi oleh pegawai yang berusia 51 - 60 tahun dengan presentase $31,6 \%$, hal ini menunjukkan usia pegawai yang ditugaskan pada bagian pengamanan tidak lagi sebanding dengan beban kerja yang diterima. Oleh karena itu pihak LAPAS hendaknya menyesuaikan beban kerja yang diberikan dengan kemampuan pegawai, sehingga dalam menyelesaikan pekerjaan pegawai tidak merasa terbebani dan tidak menurunkan semangat kerja pegawai.

Melihat dari hasil karakteristik responden berdasarkan tingkat pendidikan pegawai pengamanan LAPAS Kelas IIB Singaraja di dominasi oleh lulusan SMA sebanyak 54,7\%. Untuk meningkatkan motivasi pegawai pihak lembaga perlu mengadakan program beasiswa kepada pegawai berprestasi dan dengan kinerja yang baik, program ini tentunya akan bermanfaat bagi pegawai. Selain itu untuk mengurangi tingkat kejenuhan dalam bekerja perlu diadakannya kegiatan-kegiatan yang bertujuan untuk membangun semangat pegawai seperti misalnya melakukan senam bersama pada hari jumat atau melakukan kegiatan bersih-bersih seputaran lembaga tempat bekerja.

Berdasarkan hasil pengujian yang diperoleh, maka secara negatif beban kerja berpengaruh terhadap motivasi kerja pegawai LAPAS Kelas IIB Singaraja. Hasil penelitian ini sesuai dengan pendapat yang dikemukakan oleh Suwatno (2011) bahwa stres kerja dibagi menjadi dua taraf, yaitu taraf sedang merupakan stres yang berperan sebagai motivator dalam memberikan pengaruh positif terhadap tingkah laku kerja. Kedua, taraf tinggi merupakan stres kerja yang dialami secara berulang-ulang dan terjadi dalam jangka aktu yang lama sehingga seseorang merasa terancam, mengalami gangguan psikis dalam bekerja. Hal ini mengakibatkan beban kerja berpengaruh terhadap motivasi kerja pegawai. Hasil pada penelitian ini didukung oleh hasil penelitian yang dilakukan oleh Hardono dkk (2019), dimana beban kerja pegawai berhubungan secara signifikan dengan motivasi kerja. Beban kerja berpengaruh terhadap motivasi kerja pegawai, namun beban kerja yang diterima pegawai pengamanan LAPAS masih berada pada ketegori tinggi hal ini terdapat pada hasil analisis deskriptif. Beban kerja yang dimaksud salah satunya kelebihan kapasitas jumlah hunian pada LAPAS yang mengakibatkan bertambahnya beban pekerjaan yang diterima pegawai, hal ini tentunya menurunkan semangat kerja pegawai, Maka dari itu, pihak Lembaga sebaiknya menyesuaikan beban kerja agar motivasi kerja pegawai dapat terjamin.

Berdasarkan hasil pengujian yang diperoleh, maka diperoleh temuan bahwa variabel beban kerja memiliki pengaruh negatif terhadap kepuasan kerja pada pegawai LAPAS kelas IIB Singaraja. Hasil penelitian ini sesuai dengan teori yang dikemukakan oleh Cole et al. (2014), yang mengemukakan bahwa kelebihan beban kerja akan mengakibatkan rendahnya kepuasan kerja pegawai. Hasil penelitian ini didukung oleh hasil penelitian terdahulu yang dilakukan oleh Altaf dan Mohamad Atif (2011) yang menemukan bahwa tingkat beban kerja yang tinggi berpengaruh negatif terhadap kepuasan kerja. Pegawai pengamanan LAPAS memiliki lima tugas dan fungsi. Dari hasil analisa deskriptif yang menyatakan bahwa beban kerja termasuk kedalam kategori tinggi yang akan berdampak pada kepuasan kerja pegawai lapas. Maka dari itu pihak lapas sebaiknya lebih memperhatikan beban kerja yang diberikan kepada pegawai, selain itu melihat usia pegawai pengamanan lapas yang di dominasi oleh usia 51-60 tahun yang menunjukkan bahwa semangat kerja pada usia tersebut mulai menurun, dengan beban kerja yang tinggi tentunya akan menurunkan kepuasan kerja pegawai. Jika dilihat dari jumlah pegawai pengamanan lapas yang berjumlah 35 orang dengan kondisi pekerjaan yang beresiko tinggi dan jumlah tahanan yang melebihi kapasitas tentunya akan menyulitkan bagi pegawai yang bersangkutan. Pihak LAPAS perlu menambah jumlah pegawai pengamanan agar sebanding dengan jumlah tahanan yang terdapat di dalam LAPAS.

Berdasarkan hasil penelitian, maka diperoleh hasil bahwa variabel motivasi kerja berpengaruh positif terhadap kepuasan kerja pada pegawai LAPAS kelas IIB Singaraja. Hasil pada penelitian ini sesuai dengan pendapat dikemukakan oleh Hasibuan (2000) bahwa 
motivasi adalah dorongan yang memberikan semangat untuk melakukan pekerjaan, sehingga mampu untuk bekerja sama dengan tim, bekerja efektif, dan berintegrasi dengan baik guna mendapat kepuasan yang diharapkan. Hasil pada penelitian ini didukung oleh penelitian Prabu (2005), faktor-faktor motivasi berpengaruh signifikan terhadap kepuasan kerja pegawai. Artinya, semakin tinggi faktor-faktor motivasi yang diterima maka kepuasan kerja pegawai akan semakin tinggi. Terdapat lima indikator pengukuran motivasi kerja diantaranya: (1) Kebutuhan fisik, artinya kemampuan lembaga dalam memberikan bonus yang sesuai dengan pekerjaan maupun kinerja yang telah dilakukan. (2) rasa aman dan keselamatan, kemampuan lembaga dalam menjamin keamanan dan keselamatan pegawai, upaya yang dapat dilakukan oleh pihak lembaga adalah dengan menyediakan peralatan keamanan dan perlengkapan senjata selama melakukan penjagaan. Hal ini akan mampu menjamin keselamatan pegawai selama melakukan pekerjaan. (3) kebutuhan sosial, kemampuan lembaga dalam menciptakan hubungan baik antar pegawai. Pihak lembaga dapat melakukan kegiatan diluar jam kerja seperti piknik bersama seluruh pegawai LAPAS, atau melakukan outbond di hari libur. Hal ini akan menjalin hubungan yang harmonis antar pegawai. (4) kebutuhan akan penghargaan, kemampuan lembaga dalam menghargai prestasi kerja pegawai. Pihak LAPAS memberikan reward berupa piagam penghargaan serta hadiah berupa jam dinding berlogo dinas bagi karyawan yang memiliki kinerja yang baik selama bekerja, selain reward yang telah ditetapkan pihak lembaga dapat memberikan penghargaan berupa promosi jabatan atau pemberian bonus untuk meningkatkan semangat dan motivasi kerja pegawai. (5) kebutuhan perwujudan diri, kemampuan pihak lembaga dalam memberikan pelatihan bagi pegawai. Pihak LAPAS dapat memberikan pelatihan bela diri, mengingat resiko pekerjaan yang dihadapi, pemberian pelatihan untuk membela diri dari serangan tiba-tiba sangat diperlukan. Berdasarkan analisa deskriptif variabel motivasi kerja berada pada kategori tinggi, namun untuk meningkatkan kepuasan kerja pegawai agar lebih optimal lagi maka motivasi kerja pegawai dapat ditingkatkan dengan memperhatikan kelima indkator pengukuran tersebut.

Hasil pada penelitian ini mengindikasikan bahwa beban kerja dan motivasi kerja berpengaruh terhadap kepuasan kerja. Hal ini mengandung implikasi bahwa untuk meningkatkan kepuasan kerja pegawai, pihak lembaga atau perusahaan perlu memperhatikan beban kerja dan motivasi kerja pegawai. Agar kepuasan kerja pegawai dapat terpenuhi pihak lembaga atau perusahaan perlu memberikan perhatian serius terkait beban kerja karyawan berupa beban tugas yang sesuai dengan kompetensi dan kedudukan, serta menghindari adanya desakan waktu dalam penyelesaian pekerjaan. Selanjutnya, untuk mengembangkan motivasi kerja lembaga perlu menciptakan suasana kerja yang kondusif, apresiasi terhadap prestasi kerja karyawan, menjaga keseimbangan antara tugas dan tanggung jawab. Jika lembaga atau perusahaan belum dapat memperhatikan beban kerja dan motivasi kerja, maka kepuasan kerja belum dapat dimaksimalkan. Sebaiknya Lembaga tidak hanya fokus kepada salah satu hal baik beban kerja maupun motivasi kerja dalam upaya meningkatkan kepuasan kerja, megingat beban kerja nelalui motivasi kerja memberikan implikasi yang lebih baik terhadap kepuasan kerja.

\section{Simpulan dan Saran}

Berdasarkan hasil uji statistik dan hipotesis serta dari hasil pembahasan maka dapat diberikan kesimpulan sebagai berikut: (1) beban kerja dan motivasi kerja berpengaruh secara signifikan terhadap kepuasan kerja pada pegawai LAPAS kelas IIB Singaraja, (2) beban kerja berpengaruh secara negatif terhadap motivasi kerja pegawai LAPAS kelas IIB Singaraja, (3) beban kerja berpengaruh secara negatif terhadap kepuasan kerja pada pegawai LAPAS kelas IIB Singaraja, (4) motivasi kerja berpengaruh secara positif terhadap kepuasan kerja pada pegawai LAPAS kelas IIB Singaraja. Dari hasil penelitian yang telah dilakukan maka terdapat beberapa saran yang perlu diajukan yakni: (1) bagi Lembaga Pemasyarakatan Kelas IIB Singaraja, perlu memperhatikan beban kerja dan motivasi kerja guna meningkatkan kepuasan kerja. Kepuasan kerja pegawai dapat ditingkatkan dengan menyesuaikan beban tugas yang dengan kompetensi dan kedudukan dan menghindari adanya desakan waktu dalam penyelesaian pekerjaan. Selanjutnya motivasi kerja dapat ditingkatkan melalui memberikan 
penghargaan yang sesuai bagi pegawai berprestasi dan mendapatkan kesempatan kenaikan jabatan dan mendapatkan pelatihan kerja, (2) Bagi peneliti yang ingin melakukan penelitian mengenai variabel beban kerja, motivasi kerja, dan kepuasan kerja diharapkan agar lebih mengembangkannya dengan lebih baik, serta mengggunakan populasi dengan jumlah yang lebih banyak agar hasil penelitian dapat teruji keandalannya.

\section{Daftar Pustaka}

Altaf, A., \& Awan, M. 2011. Moderating Effect of Workplace Spirituality on

the Relationship of Job Overload and Job Satisfaction. Journal of Business Ethics, 104(1), 93-99.

Anggraini, Rati. 2019. Pengaruh Motivasi Dan Beban Kerja Terhadap Kepuasan Kerja Karyawan Pada PT. Sumber Tirta Anugrah Rezeki Pekanbaru. Skripsi Fakultas Ekonomi dan IImu Sosial. Universitas Islam Negeri Sultan Syraif Kasim Riau.

Cole,D, Phancanadeswaran, S \& Daining, C. 2014. Predictor of jobsatisfaction of licensed social works. Perceived efficacy asa mediator of the relationship between workload and job satisfaction. Journal of social service research. 31(1),1-12.

George, J.M., \& Jones, G.R. 2012. Understanding And Managing Organizational Behaviour $6^{\text {th }}$ edition. New Jersey: Person Education. Inc.

Gibson J, Ivancenvich M., \& Donely, JH. 2000. Organization: Structure, Processes, behaviour. Dalas:Business Publication. Inc.

Handoko, H. 2005. Manajemen Sumber Daya Manusia dan Personalia. Yogyakarta: BPFE UGM.

Handoko. 2010. Manajemen Personalia dan Sumber Daya Manusia. Yogyakarta:BPFE

Hardono, Indra, dkk. 2019. Pengaruh Penempatan dan Beban Kerja Terhadap Motivasi Kerja dan Dampaknya Pada Prestasi Kerja Pegawai. Jurnal Manajemen Vol 8 No 1.

Hasibuan, Melayu SP. 2000. Organisasi dan Motivasi Dasar Peningkatan Produktivitas. Jakarta: Bumi Aksara.

Hasibuan. 2014. Manajemen Sumber Daya Manusia edisi revisi.Jakarta : Bumi Aksara. Jakarta: Erlangga.

Koesomowidjojo, S.R.M. 2007. Analisis Beban Kerja. Jakarta: Raih Asa Sukses.

Mangkunegara, Anwar Prabu. 2009. Manajemen sumber Daya Manusia Perusahaan. Bandung: PT Remaja Rosdakarya Bandung.

Mustapha, Noraani dan Ghee, W. Y. 2013. Examining Faculty Workload as Antencedent of Job Satisfaction among Academic Staff of Higher Public Education on Kelantan, Malaysia. Journal Business and Management Horizons, 1(1), pp: 10-16.

Robbins, Stephen P dan Judge. Timothy A. 2008. Perilaku Organisasi. Salemba Empat, Jakarta, 2008

Sowmya, K.R., and N. Panchanatham. 2011. Factors Influencing Job Satisfaction of Banking Sector Employees in Chennai, India. Journal of law and Conflict Resolution. Vol.3(5), pp.76-79.

Steve M. Jex. 2002. Organization Behavior.A scienties Practioner approach. (New York: John Willey 5 Sons Inc, p.192.

Suwatno dan Priansa, Donni Juni. 2011. Manajemen Sumber Daya Manusia Dalam Organisasi Publik Dan Bisnis. Penerbit Cv. Alfabeta, Bandung.

Wibowo, P. A. 2012. Pengaruh Motivasi Kerja dan gaya Kepemimpinan Terhadap Kepuasan Kerja Karyawan (Studi Kasus Pada Kryawan kantor badan Kesatuan bangsa dan 
Politik Kabupaten Jepara. Doctoral dissertation. Universitas Muhammadiyah Surakarta.

Wursanto. 2010. Manajemen Personalia Manajemen Sumber Daya Manusia. Edisi Ketiga. Penerbit Ghalia Indonesia, Jakarta. 